\title{
Wyzwania dla badań włączających osoby z niepełnosprawnością intelektualną Doświadczenia własne
}

\author{
Celina Kamecka-Antczak \\ https://orcid.org/0000-0001-8476-9738 \\ Uniwersytet Mikołaja Kopernika w Toruniu \\ Mateusz Szafrański \\ https://orcid.org/0000-0001-5178-8457 \\ Uniwersytet Mikołaja Kopernika w Toruniu \\ Klaudia Wos \\ https://orcid.org/0000-0002-5000-6182 \\ Uniwersytet Mikołaja Kopernika w Toruniu
}




\section{Streszczenie}

Rozdział dotyczy prezentacji doświadczeń związanych z prowadzeniem włączających (partycypacyjnych) badań naukowych w rzeczywistości polskiej szkoły specjalnej. Badania te lokowane są w oligofrenopedagogice - pedagogice osób z niepełnosprawnością intelektualną. Uwzględniając dotychczasowe doświadczenia badaczy, w rozdziale dokonano rozważań dotyczących miejsca osób z niepełnosprawnością intelektualną w badaniach partycypacyjnych oraz wskazano bariery, które mogą występować podczas prowadzenia badań w tym paradygmacie. Do czynników determinujących te bariery należą m.in. kultura szkoły, poglądy kadry pedagogicznej, lokowanie badań dotyczących różnych obszarów funkcjonowania osób z niepełnosprawnością intelektualną na tle stereotypów kulturowych oraz występowanie badacza na określonym tle kulturowym.

\section{Słowa kluczowe}

niepełnosprawność intelektualna, partycypacja, emancypacja, bariery w badaniach naukowych.

\section{WPROWADZENIE}

Z godnie z wynikami Narodowego Spisu Powszechnego Ludności i Mieszkań z 2011 r., szacuje się, iż osoby z niepełnosprawnością w Polsce stanowią około 12,2\% ogółu społeczeństwa (GUS 2012). Natomiast występowanie niepełnosprawności intelektualnej szacuje się w granicach 1-3\% populacji generalnej (Zasępa 2016; Rusinek 2016). Wielkość tych wartości może wahać się ze względu na metodologię badań (rodzaj badań, wybrane definicje niepełnosprawności, źródło danych) oraz cechy populacji osób badanych (Zasępa 2016), bowiem w zależności od przyjętych kryteriów definicyjnych niepełnosprawność intelektualna może być ujmowana jako: objaw choroby, zwracając uwagę na jej etiologię i patogenezę (typ kliniczno-medyczny), stan podlegający regulacjom prawno-administracyjnym (typ praktyczny) i wreszcie ocena procesów psychicznych, poznawczych i przystosowawczych (typ społeczno-psychologiczny) (Chodkowska, Szabała 2012). W Polskim systemie prawnym przyjmuje się definicje i stopnie niepełnosprawności intelektualnej opracowane przez Światową Organizację Zdrowia (World Health Organization, skrót ang. WHO) zawarte w Międzynarodowej Statystycznej Klasyfikacji Chorób i Problemów Zdrowotnych w wersji ICD-10 oraz Amerykańskie Towarzystwo Psychiatryczne (American Psychiatric Association, skrót ang. APA) zamieszczone w Diagnostycznym i Statystycznym Podręczniku Zaburzeń Psychicznych w wersji DSM-IV oraz nowszej DSM-V.

Piąte, zaktualizowane wydanie podręcznika (2013) zmienia termin upośledzenie umysłowe/niedorozwój umysłowy (obecny we wcześniejszych wersjach) na określenie niepełnosprawność intelektualna. Takie rozwiązanie zostało zaproponowane już w 2007 r. w Atlasie Niepełnosprawności Intelektualnej (WHO 2007), gdzie termin niepełnosprawność intelektualna uznano jako mniej stygmatyzujący, jak również bardziej odpowiadający współczesnym przemianom i tendencjom normalizacyjnym (Rusinek 2016). W polskiej rzeczywistości nadal jednak stosuje się oba te pojęcia zamiennie, szczególnie w zakresie rozwiązań prawnych. 
Zatem według DSM-V niepełnosprawność intelektualna jest „zaburzeniem rozpoczynającym się w okresie rozwoju i obejmuje deficyty zarówno w zakresie funkcjonowania intelektualnego, jak i adaptacyjnego w obszarach dotyczących rozumienia pojęć, funkcjonowania społecznego oraz w dziedzinach praktycznych" (Gałecki, Święcicki 2015: 15). Autorzy podręcznika DSM-V wyróżniają także trzy kryteria, które dopełniają przedstawioną definicję, zakładając, że:

1. Deficyty w zakresie funkcjonowania intelektualnego (m.in. wnioskowanie, myślenie abstrakcyjne, uczenie się) muszą zostać stwierdzone podczas oceny klinicznej, a także zostać potwierdzone poprzez standaryzowane (indywidualnie dobrane do pacjenta) testy inteligencji;

2. Deficyty w zakresie realizacji standardów rozwojowych oraz społecznych i kulturowych manifestują się poprzez nieodpowiednie przystosowanie się, co w konsekwencji skutkuje ograniczoną niezależnością oraz odpowiedzialnością;

3. Rozpoczęcie występowania deficytów musi nastąpić w okresie rozwojowym (Gałecki, Święcicki 2015).

Należy jednocześnie pamiętać, że mimo przyznanych przez organizacje kodów klasyfikacji, niepełnosprawność intelektualna nie jest ani chorobą, ani zaburzeniem psychicznym, lecz stanem, w którym znajduje się dana osoba, który, jak pisze Baczała, może ulegać zmianie dzięki „prawidłowemu procesowi rehabilitacji psychologicznej, pedagogicznej i społecznej” (Baczała 2012: 43). Współczesne trendy wynikające z kontynuacji procesu humanizacji stosunków międzyludzkich implikują kolejną zmianę w nazewnictwie. Zaleca się używanie spójnika „z" między cechą niepełnosprawności, a osobą, która ją posiada. Z semiotycznego punktu widzenia wszystkie zaproponowane terminy mają wspólny desygnat, a spór o nazewnictwo i towarzyszący mu chaos, jak zauważają Gustavsson i Zakrzewska-Manterys, nie jest kwestią języka, a „przejawem zachodzącego procesu zmiany postaw i pluralizacji kryteriów orzekania o normalności" (Gustavsson, Zakrzewska-Manterys 1997: 24). Zatem istotne jest nie samo rozstrzygnięcie, którego pojęcia używać, tylko znaczenie przypisywane $\mathrm{w}$ toku historii określanej nim grupie. Znaczenie to nie wynika z poprawności politycznej, ale z reorganizacji struktur społecznych (Zakrzewska-Manterys 2010). Dodanie spójnika „Z" ma znaczenie nie tyle w próbach odejścia od pojęcia pejoratywnie naznaczonego, co w próbie przejścia do pojęcia nastawionego bardziej egzystencjalnie. Pojęcia, które ujmuje człowieka jako osobę wraz z jej światem i zachodzącymi w nim relacjami („ludzkie bycie w świecie”) oraz osobę podejmującą wysiłek w celu jego zrozumienia (Zakrzewska-Manterys 2010). W takim znaczeniu używać będziemy terminu osoba $\mathrm{z}$ niepełnosprawnością intelektualną.

Postrzeganie osób z niepełnosprawnością intelektualną determinować mogą trzy główne modele kształtujące się na przestrzeni lat, będące niejako etapami, które bezpośrednio związane są m.in. z regulacjami prawnymi, zmianami społecznymi czy rozwojem socjoekonomicznym w Polsce: model instytucjonalny, model konsumencki (rozwojowy) oraz model obywatelski (Firkowska-Mankiewicz 2006) (tab.1). Przyjęcie określonej perspektywy determinuje wszelkie działania podejmowane na rzecz oraz wraz z osobami z niepełnosprawnością intelektualną. Zmiany te miały również bezpośredni wpływ na tworzenie się nowych paradygmatów badawczych (Mercer 2004). Można zauważyć zatem tutaj bezpośrednią zależność nauki od regulacji prawnych czy działań praktycznych. 


\section{Model instytucjonalny/medyczny}

- Model dominujący do końca lat 60. XX w.

- Główne założenie: izolacja od społeczeństwa, umieszczanie osób z niepełnosprawnością intelektualną w zamkniętych instytucjach totalnych (szpitale psychiatryczne, zakłady opiekuńcze).

- Podstawowa relacja: pacjent vs. profesjonalista/lekarz.

- Cel: zaspokojenie podstawowych potrzeb pacjenta oraz opieka i leczenie.

\section{Model konsumencki (rozwojowy) - era deinstytucjonalizacji}

- Główne założenie: wszystkie osoby z niepełnosprawnością intelektualną (niezależnie od stopnia) mogą się rozwijać oraz uczyć.

- Cel: tworzenie dostosowanych do stopnia niepełnosprawności technik oraz metod nauczania i rehabilitacji, które rozwijają zakres umiejętności klientów.

- Wielkie placówki opiekuńcze zostały zastąpione mniejszymi placówkami środowiskowymi, np. warsztatami terapii zajęciowej (WTZ) bądź dziennymi centrami aktywności.

\section{Model obywatelski/społeczny}

- Główne założenie: odejście od tworzenia specjalnie przystosowanych placówek oraz sztucznie wytwarzanych sytuacji rozwoju na rzecz wspierania tej grupy $\mathrm{w}$ ich rodzinnych miejscowościach, rodzinach czy domach (m.in. poprzez tworzenie formalnych i nieformalnych grup wsparcia).

- Tworzenie formalnych oraz nieformalnych grup wsparcia, które wynikają z realnych problemów życia codziennego.

- Cel: przystosowanie środowiska do potrzeb tej grupy osób.

Źródło: opracowanie własne na podstawie Firkowska-Mankiewicz (2006).

Społeczny model niepełnosprawności wyraźnie wybrzmiewa również w ratyfikowanej przez Polskę w 2012 r. Konwencji ONZ o Prawach Osób Niepełnosprawnych (WHO 2006). Jednym z priorytetów Konwencji jest włączanie tematyki niepełnosprawności do wszystkich kwestii związanych z rozwojem społecznym (disability mainstreaming), a więc również w obszar badań naukowych. Powstaje zatem konieczność zaistnienia nowej roli, jaką osoba niepełnosprawna może odegrać w badaniach.

\section{POSZUKIWANIE MIEJSCA DLA OSOBY Z NIEPEŁNOSPRAWNOŚCIĄ INTELEKTUALNĄ W PROCESIE BADAWCZYM}

Wszelkie próby wyjaśniania istoty niepełnosprawności muszą być realizowane przy aktywnym i świadomym udziale osób z niepełnosprawnością, tak by obraz zjawiska, jakim 
jest niepełnosprawność, nie był tworzony wyłącznie przez pełnosprawnych badaczy i badaczki, z których część rości sobie prawo do definiowania i opisywania tego, co nie jest ich doświadczeniem (McVilly, Dalton 2006; Parchomiuk 2014). Stawia to warunki podmiotowego traktowania osób, uprawomocnienie w badaniach grup dotychczas nieobecnych, dostępności badanych osób do procesu badawczego. Barton (2005) badanie (naukowe) postrzega jako akt społeczny interakcji międzyludzkich lub/i międzygrupowych, które nawiązywane są w celu rozwiązywania problemów o charakterze strukturalnym, etycznym czy politycznym (Barton 2005). Kierując się wskazaną definicją, badacze stoją przed wyzwaniem uczynienia osoby z niepełnosprawnością intelektualną podmiotem realizowanych działań, starając się identyfikować realne potrzeby oraz możliwości tychże osób (Wołowicz 2018).

Odpowiedzią na powyższe postulaty są badania prowadzone $\mathrm{w}$ duchu paradygmatu włączającego. Badania włączające mogą być projektami o zróżnicowanym udziale pełnoi niepełnosprawnych. Pojęcie to zostało wprowadzone w kontekście badań z udziałem niepełnosprawnych intelektualnie $\mathrm{w}$ stosunku do tych projektów, w których niepełnosprawni występują jako aktywni badacze, „inicjatorzy pomysłów, projektanci badań, zbierający materiał, dokonujący jego analizy, autorzy opracowań, upowszechniający wyniki i ich użytkownicy" (Johnson, Minogue, Hopkins 2014: 77). W paradygmacie włączającym miesza się zatem badania partycypacyjne oraz emancypacyjne bądź też ich elementy łączone z innymi metodologiami (Oliver 1997). W zależności od stopnia zaangażowania osób z niepełnosprawnością w proces badawczy badania prowadzone w duchu paradygmatu włączającego możemy podzielić na 3 typy (bądź etapy): badania partycypacyjne, badania włączające oraz badania emancypacyjne.

Tabela 2. Badania prowadzone w duchu paradygmatu włączającego

\section{Partycypacja}

- Proces wzajemnego uczenia się (dialogu i wymiany wiedzy) (wzajemnego uczenia się) między badaczem i osobami badanymi.

- Badacze stają się bardziej „dostępni” dla osób z niepełnosprawnościami.

\section{Włączenie}

- Udzielenie osobom z niepełnosprawnością wysokiego poziomu kontroli w procesie badawczym, nadanie im wiodącej roli.

\section{Emancypacja}

- Osoby z niepełnosprawnością sprawują kontrolę nad całym procesem badawczym, co stanowi część szerszego procesu empowermentu.

Źródło: opracowanie własne na podstawie Zarb (1997), Parchomiuk (2016).

Etapy te rozciągnięte są na kontinuum paradygmatu włączającego od partycypacji jako procesu aktywnego współtworzenia wiedzy, przez dzielenie się nią, nabywanie kom- 
petencji empowermentu, aż do społecznej zmiany czyli emancypacji. Etapy te muszą następować kolejno, a dodatkowo zależne są one od gotowości społecznej oraz od gotowości uczestników badania.

Polskie badania w nurcie paradygmatu włączającego to przede wszystkim właśnie badania partycypacyjne. Do autorów polskich badań partycypacyjnych nad niepełnosprawnością zaliczyć możemy m.in.: Kumaniecką-Wiśniewską (2006), Rzeźnicką-Krupę (2007), Woynarowską (2010), O. Koenig (2011), Żytę (2011), Cytowską (2012), Lindyberg (2012), Krzemińską (2012), Borowską-Besztę (2013) - badaczki te, analizując różne aspekty życia osób z niepełnosprawnością intelektualną, wykorzystują metody stwarzające możliwość aktywizowania badanej grupy, wspólnego docierania do ważnej dla badanych wiedzy i poszukiwania jej znaczeń, a także jej upowszechniania (szerzej u: Parchomiuk 2014).

Celem niniejszego opracowania jest prezentacja dwóch procesów badawczych realizowanych przez autorów tego rozdziału, które nazwać możemy badaniami partycypacyjnymi ( $w$ nurcie paradygmatu włączającego). Badania te były prowadzone z udziałem osób z niepełnosprawnością intelektualną w Polsce. Następnie przedstawione zostaną wynikające z kontekstu kulturowo-społecznego oraz systemowo-instytucjonalnego wyzwania, które były udziałem autorów podczas aktywności badawczej. Od kilku lat staramy się wdrażać badania partycypacyjne w swojej aktywności badawczej, wykorzystując do tego w dużej mierze projekty społeczne, które dają możliwość realnego włączenia osób z niepełnosprawnością intelektualną nie tylko w proces badawczy, ale także w szerszy proces zmierzający do zmiany społecznej poprzez stosowanie $w$ praktyce wypracowanych w procesie badawczym rozwiązań.

Podstawą do opracowania założeń realizowanych badań były zasady badań partycypacyjnych zaproponowane przez Parchomiuk (2016). Autorka wymienia następujące (ważne zarówno z perspektywy badaczy, jak i uczestników badania) reguły:

1) Bezpośredni udział osób z niepełnosprawnością w procesie konkretyzacji problemu badawczego, jego definiowaniu, analizie oraz próbie rozwiązania. Stawianie uczestników badania w pozycji pełnoprawnych (współ)uczestników całego procesu badawczego, mających prawo do wyrażania własnych opinii oraz samodecydowania. Korzyści: dokonanie trafnej analizy badanego wycinka rzeczywistości oraz zaproponowanie rozwiązań dostosowanych do realnych potrzeb grupy.

2) Rozwijanie zasobów osobistych uczestników badań poprzez wzajemne ich odkrywanie oraz wzmacnianie poczucia kontroli nad kreowaniem własnej rzeczywistości. Istotny element tego procesu stanowi wymiana wiedzy między badaczem a badanymi. Korzyści: wzrastający poziom świadomości własnych zasobów może motywować do wprowadzenia zmian we własnym życiu - poprawy jakości życia.

3) Wzajemne uczenie się prowadzi do generowania nowej wiedzy istotnej również dla badacza w procesie tzw. wzmacniającej partycypacji. Korzyści: proces badawczy jako część procesu empowermentu (Parchomiuk 2016).

Podstawowym celem w każdym prowadzonym działaniu badawczym powinna być troska o dobro bezpośredniego odbiorcy podejmowanego procesu badawczego, którego upatrywać powinno się nie tyle w środowisku naukowym (np. czytelnikach tego artykułu), co właśnie w uczestnikach projektu badawczego - w tym przypadku osobach z niepełnosprawnością intelektualną. 


\section{ANALIZA BADAŃ WŁASNYCH W PERSPEKTYWIE PARADYGMATU WŁĄCZAJĄCEGO}

Poniżej opisane zostaną dwa projekty badawcze, których uczestnikami były osoby z niepełnosprawnością intelektualną. Każdy z projektów zostanie opisany pod kątem wytycznych, które zostały opracowane na podstawie literatury przedmiotu dotyczącej badań partycypacyjnych (m.in. zasad przedstawionych we wcześniejszej części tekstu). Wyróżniono następujące kryteria: wspólne wytwarzanie wiedzy, partycypacja, motywacja, upowszechnianie wytworzonej wiedzy (działanie na rzecz środowiska lokalnego i ogólnokrajowego) oraz proces empowermentu (w przypadku jednego projektu). Celem porównania nie będzie analiza wyników badań, lecz samego procesu: od pomysłu na badania do jego realizacji.

\section{CZYM JEST DLA MNIE DOBRO WSPÓLNE? - WIDEOPREZENTACJA}

Grupę badawczą stanowiło 9 osób z niepełnosprawnością intelektualną, uczniowie specjalnej zasadniczej szkoły zawodowej oraz szkoły przysposabiającej do pracy. Celem projektu było poznanie postrzegania idei dobra wspólnego przez uczestników projektu, stanowiącej szerszy element procesu rozwijania kompetencji obywatelskich uczniów szkół specjalnych. Podłoże teoretyczne stanowiły rozważania nad aktywnością obywatelską oraz edukacją dla demokracji osób z niepełnosprawnością intelektualną. Badania przyjęły formę konkursu na videoprezentację dla uczestników projektu, które następnie stały się materiałem do analizy dla badaczy (zarówno pod względem treści, jak i aranżacji filmu).

Głównym założeniem konkursu było samodzielne przygotowanie materiałów wideo przez uczniów. W celu realizacji nagrania udostępniona została dla uczniów kamera wideo oraz przestrzeń szkolna, np. pusta klasa lekcyjna. Aktywność własną uczniów poprzedziły dwa warsztaty zrealizowane przez badaczy. Warsztat pierwszy dotyczył idei dobra wspólnego oraz dotykał tematyki przynależności społecznej, społeczności lokalnej, aktywności obywatelskiej oraz współpracy. Tutaj prowadzona była również obserwacja uczestnicząca. Warsztat drugi poświęcony został sztuce wystąpień przed kamerą. Zawierał ćwiczenia werbalno-oddechowe, pracę z postawą ciała, a także z doborem tła, ubioru i atrybutów do planowanego wystąpienia. Autoprezentacyjne nagrania były przygotowywane w pewnym odstępie czasowym od samych warsztatów, aby uczniowie mieli czas na dokonanie własnej refleksji. Nagrodą konkursową był wyjazd dla jednego ucznia (wraz z opiekunem) do Brukseli - stolicy Unii Europejskiej (nagroda została pozyskana we współpracy z członkiem Parlamentu Europejskiego) oraz nagrody rzeczowe dla pozostałych uczniów. Jury konkursu stanowili: dyrektor szkoły, poseł do Parlamentu Europejskiego oraz wieloletnia była nauczycielka szkoły specjalnej - obecnie pracownik naukowy. Forma nagrania wideo umożliwiła dalsze wykorzystywanie prac konkursowych w edukacji obywatelskiej uczniów tej placówki.

Poniżej wskazano, które elementy tego projektu pozwalają stwierdzić, że było to badanie partycypacyjne. Podczas analizy posłużono się wymienionymi wcześniej kategoriami. 
Tabela 3. Analiza badań własnych - dobro wspólne

\begin{tabular}{|c|c|}
\hline KATEGORIA & OPIS \\
\hline $\begin{array}{l}\text { Wspólne } \\
\text { wytwarzanie wiedzy }\end{array}$ & $\begin{array}{l}\text { Wspólna praca nad rozwijaniem kompetencji spo- } \\
\text { łecznych oraz obywatelskich - warsztaty dotyczące } \\
\text { obywatelstwa, występowania przed kamerą. }\end{array}$ \\
\hline Partycypacja & $\begin{array}{l}\text { Pomysł na realizację konkursu (oraz wykorzystania go } \\
\text { jako formy badań) powstał w ramach jednego ze spo- } \\
\text { tkań szkolnego koła Młodych Obywateli, które prowa- } \\
\text { dzone jest przez nauczyciela placówki stale współpra- } \\
\text { cującego z badaczami (autorami artykułu). Uczniowie } \\
\text { w ramach jednego ze spotkań podjęli dyskusję nad } \\
\text { tym, co oni jako mieszkańcy miasta mogą dla niego } \\
\text { zrobić. Kolejno do tej kategorii zaliczyć można formę } \\
\text { realizacji zadania: uczniowie samodzielnie przygoto- } \\
\text { wywali każdy z aspektów swojego wystąpienia: od tre- } \\
\text { ści po scenerię, ubiór czy dobór atrybutów. }\end{array}$ \\
\hline Motywacja & $\begin{array}{l}\text { Atrakcyjna nagroda w formie wyjazdu do Brukseli dla } \\
\text { zwycięzcy konkursu. }\end{array}$ \\
\hline $\begin{array}{l}\text { Upowszechnianie } \\
\text { wytworzonej wiedzy } \\
\text { (działanie na rzecz } \\
\text { środowiska lokalnego } \\
\text { i ogólnokrajowego) }\end{array}$ & $\begin{array}{l}\text { Nagrania były wykorzystywane przez nauczycieli } \\
\text { podczas zajęć z zakresu edukacji obywatelskiej, po- } \\
\text { nadto uczestnicy projektu występowali w roli „szkol- } \\
\text { nych ekspertów”, opowiadając w klasach o zdobytym } \\
\text { doświadczeniu. }\end{array}$ \\
\hline Proces empowermentu & - \\
\hline
\end{tabular}

Źródło: opracowanie własne.

\section{INNOWACJA SPOŁECZNA „WYZWANIA ŻYCIA” - WSPÓŁTWORZENIE NARZĘDZIA DO EDUKACJI SEKSUALNEJ W SZKOŁACH}

Kolejne badania były elementem większego projektu - innowacji społecznej, której celem było stworzenie edukacyjnej gry planszowej „Wyzwania życia”, stanowiącej narzędzie dydaktyczne dla osób prowadzących zajęcia z zakresu edukacji seksualnej. Narzędzie powstało w ramach grantu „Innowacje na ludzką miarę - wsparcie rozwoju mikroinnowacji w obszarze usług opiekuńczych dla osób zależnych” Program Operacyjny Wiedza Edukacja Rozwój 2014-2020, współfinansowanego z Europejskiego Funduszu Społecz- 
nego. Realizacja projektu trwała od czerwca do grudnia 2017 r. Celem podejmowanych działań było stworzenie narzędzia (w tym przypadku gry planszowej), które odpowiadać będzie na realne potrzeby i problemy osób z niepełnosprawnością intelektualną w zakresie własnej seksualności. W projekcie udział wzięło dwudziestu pełnoletnich uczniów z niepełnosprawnością intelektualną dwóch szkół przysposabiających do pracy w Toruniu. Badania były realizowane w ciągu trwania całego projektu - na jego początku (w celu poznania poziomu wiedzy uczestników), w trakcie jego trwania (w ramach obserwacji) oraz po jego zakończeniu (w celu weryfikacji efektywności narzędzia). Do realizacji badań wstępnych oraz końcowych wykorzystano specjalnie opracowaną ankietę, która była dostosowana do potrzeb osób z niepełnosprawnością intelektualną - odpowiedzi na pytania $\mathrm{w}$ ankiecie były przedstawione $\mathrm{w}$ skali kolorów (od czerwonego, który oznaczał „nie”, „nie zgadzam się" itp., do zielonego, który oznaczał „tak”, „zgadzam się”). Pytania w ankiecie były możliwie krótkie oraz przystępne językowo.

Cały projekt jest ciekawym przykładem paradygmatu włączającego „w praktyce”. Główne założenie opierało się bowiem na tym, iż uczniowie są ekspertami w zakresie własnej seksualności, w związku z tym to oni mówią o tym, z jakimi problemami w tym zakresie się zmagają, jakie mają oczekiwania i czego chcieliby się dowiedzieć (wszystko odbywało się w formie pracy warsztatowej). W kolejnej fazie projektu - tworzeniu gry, uczniowie również odgrywali istotną rolę, stając się współtwórcami narzędzia. Razem $\mathrm{z}$ grupą testowane były bowiem pierwsze formy pytań w grze, jej opracowanie graficzne, zasady oraz funkcje, jakie ma spełniać. Wszystkie wskazówki uzyskane w ramach cotygodniowych spotkań zostały wykorzystane do stworzenia narzędzia możliwie najbardziej odpowiadającego potrzebom uczniów (w tym przypadku reprezentantów młodych osób z niepełnosprawnością intelektualną). Co ciekawe, okazało się, że wypracowane rozwiązania równie dobrze sprawdzają się w szkołach ogólnodostępnych w pracy z młodzieżą $\mathrm{w}$ tzw. normie intelektualnej oraz dorosłych osób jako forma edukacyjno-rozrywkowa. Potwierdziła się zatem teza, która przyświecała realizacji projektu, że w zakresie seksualności osoby z niepełnosprawnością intelektualną nie różnią się od osób w tzw. normie.

Tabela 4. Analiza badań własnych - seksualność osób z niepełnosprawnością intelektualną

\begin{tabular}{|l|l|}
\hline \multicolumn{1}{|c|}{ KATEGORIA } & \multicolumn{1}{c|}{ OPIS } \\
\hline $\begin{array}{l}\text { Wspólne } \\
\text { wytwarzanie wiedzy }\end{array}$ & $\begin{array}{l}\text { Poznanie poziomu własnej wiedzy, weryfikowanie } \\
\text { swoich kompetencji przez osoby z niepełnosprawno- } \\
\text { ścią intelektualną, wspólne poszukiwania obszarów, } \\
\text { w których chcieliby rozwijać swoją wiedzę i kompe- } \\
\text { tencje. Wymiana wiedzy między uczestnikami projek- } \\
\text { tu a badaczami, co umożliwiło stworzenie diagnozy } \\
\text { poziomu wiedzy, kompetencji i potrzeb osób z niepeł- } \\
\text { nosprawnością intelektualną w zakresie seksualności. }\end{array}$ \\
\hline
\end{tabular}


Tabela $4 \mathrm{~cd}$.

\begin{tabular}{|l|l|}
\hline \multicolumn{1}{|c|}{ KATEGORIA } & \multicolumn{1}{c|}{ OPIS } \\
\hline Partycypacja & $\begin{array}{l}\text { Uczniowie na każdym etapie projektu pełnili rolę } \\
\text { ekspertów - od procesu konceptualizacji przez opra- } \\
\text { cowywanie prototypów do ukazania się produktu } \\
\text { finalnego. Wyniki zarówno badań wstępnych, jak } \\
\text { i obserwacji uczestniczącej w trakcie projektu były } \\
\text { analizowane z uczestnikami oraz formułowane były } \\
\text { wspólne wnioski w celu dalszej pracy. }\end{array}$ \\
\hline Motywacja & $\begin{array}{l}\text { Udział w ogólnopolskim projekcie, tworzenie roz- } \\
\text { wiązania, które potencjalnie będzie wykorzystywane } \\
\text { przez wiele osób w całej Polsce. }\end{array}$ \\
\hline $\begin{array}{l}\text { Upowszechnianie } \\
\text { wytworzonej wiedzy } \\
\text { (działanie na rzecz } \\
\text { środowiska lokalnego }\end{array}$ & $\begin{array}{l}\text { Gra stanowi aktualnie narzędzie do edukacji seksu- } \\
\text { alnej w kilkunastu placówkach przeznaczonych dla } \\
\text { osób z niepełnosprawnością intelektualną w Polsce. }\end{array}$ \\
\hline Proces empowermentu & $\begin{array}{l}\text { Cały projekt opierał się na idei prawa do edukacji } \\
\text { seksualnej osób z niepełnosprawnością intelektualną, } \\
\text { rozwijania umiejętności mówienia o niej oraz stanowił } \\
\text { krok w zakresie normalizacji. Idąc dalej, podejmowane } \\
\text { działania miały na celu doprowadzenie do zmiany po- } \\
\text { staw społecznych oraz stereotypów dotyczących sek- } \\
\text { sualności osób z niepełnosprawnością intelektualną. }\end{array}$ \\
\hline
\end{tabular}

Źródło: opracowanie własne.

\section{BARIERY DLA BADAŃ WŁĄCZAJĄCYCH OSOBY Z NI - Z PRAKTYKI MŁODEGO BADACZA}

Nasze dotychczasowe doświadczenia w prowadzeniu badań włączających osoby z niepełnosprawnością intelektualną upoważniają do wskazania problemów, które mogą występować w procesie badawczym. Mogą być one wywoływane przez wiele czynników, m.in. kulturę szkoły, poglądy kadry pedagogicznej, lokowanie badań dotyczących różnych obszarów funkcjonowania osób z niepełnosprawnością intelektualną na tle stereotypów kulturowych oraz występowanie badacza na określonym tle kulturowym. W tym miejscu zaznaczyć trzeba jednak, iż opisane poniżej problemy nie dotyczą jedynie dwóch pro- 
jektów przedstawionych w poprzedniej części, a stanowią zbiór obserwacji oraz refleksji z kilku innych podejmowanych dotychczas badań.

Szkoła jest instytucją, która ma swoje określone miejsce w kulturze i jednocześnie posiada własną kulturę. Według Taylora kultura, czyli cywilizacja w szerokim etnograficznym sensie, jest złożoną całością, która obejmuje wiedzę, wierzenia, sztukę, moralność, prawo, obyczaje oraz wszelkie inne zdolności i nawyki zdobyte przez człowieka jako członka społeczeństwa (Taylor 1871). W ujęciu autora szkoła jest częścią tej cywilizacji, czyli kultury. Uczniowie uczęszczający do niej są zaś członkami określonej kultury szkoły. Kultura szkoły w ujęciu instytucjonalnym i wspólnotowym determinowana jest przez przekonania, poglądy i postawy członków tej kultury - m.in. uczniów, nauczycieli i dyrektorów (Burszta 1998). Szkoła specjalna, stanowiąca teren badań, jest zdeterminowana kulturą niepełnosprawności, utożsamianą przez nas z urzeczywistnianiem praw osób z niepełnosprawnością i przełamywaniem stereotypów wobec nich (Brown 2002). Zgodnie z tym założeniem uczniowie z niepełnosprawnością intelektualną są czynnymi uczestnikami badań naukowych.

Metodologiczne wyzwania podczas prowadzenia badań naukowych w szkole specjalnej już na początku wszczęcia procedury ich realizacji stanowią dyrektorzy szkół. Po zrealizowaniu wszelkich formalnych wymagań (czasami trwających długo z uwagi na utrudniony kontakt z dyrektorami) - podjęciu decyzji o możliwości prowadzenia badań w szkole, przygotowaniu listów z rekomendacjami, przedstawieniu przez badaczy założeń badań, celów, metod, technik i narzędzi badawczych następuje dobór próby badawczej do badań. W dobór ten w sposób autokratyczny ingerują dyrektorzy. Według ich oczekiwań kierowniczych szkoła, którą prowadzą, ma być najlepsza. W związku z tym uczestnicy badań są dobierani przez dyrektorów. W praktyce oznacza to wybór „najlepszych” jednostek spośród wszystkich uczniów w szkole. Pozbawia to uczniów realizacji cech dobrowolności udziału w badaniach podczas ich rekrutowania. Takie okoliczności sprzyjają też fałszywemu pojmowaniu wizerunku własnej szkoły przez dyrektorów, w którym chcą oni zapobiec ujawnieniu ewentualnych negatywnych aspektów funkcjonowania szkoły, utraty pozycji i prestiżu szkoły. Najważniejszym jednak skutkiem opisywanego podejścia kierownictwa szkoły (lub innej placówki) jest naruszenie rzetelności prowadzonych badań naukowych. Bariery dyrektorów szkół wobec badaczy podyktowane są również zdarzającym się nieprofesjonalnym podejściem badaczy. Dyrektorzy zobowiązani są do chronienia swoich uczniów i zabezpieczania ich przed „fałszywymi” badaczami, uznając podmiotowość osób z niepełnosprawnością.

Kolejne bariery podczas prowadzenia badań włączających osoby z niepełnosprawnością intelektualną związane są z indywidualnymi poglądami nauczycieli. „Wasze badania nie mają sensu wśród moich uczniów”, „to jest dla nich za trudne”, „te badania wam nie wyjdą”, "może w innej szkole lepiej wam wyjdą te badania” to częste sugestie nauczycieli na pomysł włączania osób z niepełnosprawnością w badania naukowe. Według nich prawdopodobnie najlepszym rozwiązaniem byłoby ograniczenie kontaktu niepełnosprawnych uczestników badań z eksploratorami. Nauczyciele często nie podchodzą z entuzjazmem do udziału w badaniach swoich uczniów. Sceptycyzm ten może być spowodowany obawą przed krytyką ich pracy, mimo że badania nie dotyczą przecież jej oceny. 
Za inne czynniki związane z kulturą szkoły, które utrudniają prowadzenie badań włączających, uznać można przymus zwalniania uczniów z zajęć, niską frekwencję uczniów w szkole w dniu prowadzenia badań, trudności logistyczne związane z małą dostępnością wolnych sal zajęciowych.

W pedagogice specjalnej, a w zasadzie jej subdyscyplinie - oligofrenopedagogice występuje wiele obszarów do zbadania. Zaliczyć do nich można różne aspekty związane $\mathrm{z}$ dorosłością i starością osób $\mathrm{z}$ niepełnosprawnością intelektualną. Jednak wybierane do badań obszary badawcze są często nacechowane stereotypami. Same osoby z niepełnosprawnością intelektualną $\mathrm{w}$ polskim społeczeństwie należą do grupy marginalizowanych i defaworyzowanych. Społeczeństwo (również nauczyciele) wykluczają osoby z niepełnosprawnością intelektualną z podejmowania różnych ról społecznych, m.in. uczestników eksploracji naukowych. Podczas prowadzenia badań włączających dotyczących kompetencji obywatelskich jedna z nauczycielek zapytała: „po co badać u osób z niepełnosprawnością intelektualną kompetencje obywatelskie i je rozwijać, skoro nie mogą głosować w wyborach, bo są ubezwłasnowolnione?". W tej sytuacji uwidacznia się podwójne stygmatyzowanie osób z niepełnosprawnością intelektualną.

Prowadzący badania występuje na określonym tle kulturowym, np. terenie badań, z którym się identyfikuje. Według Gajdzicy „opisanie, zrozumienie i wyjaśnienie badanego wycinka rzeczywistości możliwe jest nie tylko z byciem w badanym świecie, ale także w związku z aktywnym jego zmienianiem. Rola taka musi łączyć się z zaangażowaniem emocjonalnym badacza w postrzeganie badanej rzeczywistości” (Gajdzica 2013: 155). Aktywne uczestnictwo i zaangażowanie emocjonalne mogą zniekształcać eksplorowaną rzeczywistość. Zbytnia śmiałość badacza w terenie może zaburzać wyniki badań. Ważne jest zachowanie przez badacza pewnej neutralności i bezstronności oraz nieingerowanie w prywatne życie badanych (Geertz 2003; Parchomiuk 2014; Niedbalski 2016). Nie każdy badacz może mieć również predyspozycje do prowadzenia badań naukowych z osobami z niepełnosprawnością intelektualną. Nie zna specyficznych potrzeb badanych i w związku z tym nie potrafi dotrzeć do świata znaczeń tych osób. Perspektywa włączenia nakłada na badacza obowiązek dotarcia do świata znaczeń osób badanych, odczytywanego z zebranych danych w procesie ich interpretacji. Kluczowe znaczenie badań włączających osoby z niepełnosprawnością intelektualną wyraża się zatem w uzyskaniu wiedzy, która uwzględnia ich głosy, odzwierciedla subiektywną percepcję rzeczywistości, nadawane jej znaczenia oraz oceny z perspektywy ich potrzeb i możliwości. Badacz może mieć także problemy w komunikowaniu się z grupą badawczą, np. nie znając alternatywnych metod komunikacyjnych. Sam jest utwierdzony w ableistycznych definicjach oraz w uprzedzeniach i stereotypach wobec eksplorowanej problematyki.

\section{DYSKUSJA}

W paradygmacie włączającym podkreśla się rolę osobistych doświadczeń osób z niepełnosprawnością w tworzeniu rzetelnego i trafnego obrazu niepełnosprawności. Zobowiązuje to badacza do dotarcia do świata znaczeń osób badanych (ich subiektywnej percepcji 
rzeczywistości), co odbywa się zawsze w procesie interpretacji zebranych danych. Występując w roli badaczy, nigdy jednak nie wiemy, na ile nasza interpretacja świata za pomocą utworzonych przez nas kategorii zgodna jest ze schematami kategoryzacji i interpretacji przyjętymi w badanej społeczności (Balcazar i in. 1998; Bielecka-Prus 2013; Wołowicz 2018). Wychodząc z założenia, że możliwe jest opisanie świata (światów) uczestników badania w sposób możliwie zbliżony do rzeczywistości, obowiązkowo w procesie badawczym należy uwzględnić doświadczenia i interpretację samych badanych. Jeśli weźmie się wówczas pod uwagę niepełnosprawność, to badane konceptualizacje na przykład „obywatelstwa” czy „seksualności” nabiorą innych znaczeń i tylko zmiana myślenia o nich może doprowadzić do społecznej emancypacji tej grupy. Pedagogika emancypacyjna nie dotyczy zatem tylko zmiany w grupie dyskryminowanej, ale przede wszystkim wyzwolenia grupy dominującej od panującej perspektywy ableistycznej. Podejście partycypacyjne jest ściśle związane z aktywnością społeczno-polityczną osób z niepełnosprawnością, która zawsze wychodzić będzie poza samą sytuację badawczą. Skoro paradygmat włączający odwołuje się do społecznego modelu niepełnosprawności (wskazującego na bariery społeczne) wydaje się istotne, by w badaniach wziąć pod uwagę również perspektywę „upośledzającego społeczeństwa”, które kreuje zjawisko niepełnosprawności.

Należy zatem postawić pytanie, w jaki sposób zorganizować badania, by miały one wymiar systemowy i faktycznie prowadziły do emancypacji grupowej osób $\mathrm{z}$ niepełnosprawnością? W jaki sposób stworzyć trwałą i szeroko zakrojoną współpracę między organizacjami pozarządowymi zrzeszającymi osoby z niepełnosprawnościami a ośrodkami badawczymi? Czy przestrzeń społeczna poza ściśle określonym obszarem badawczym jest przygotowana na grupową emancypację osób z niepełnosprawnością? W jaki sposób jako badacze oraz działacze na rzecz osób z niepełnosprawnością możemy tworzyć sposobność dokonania zmian szerszych, radykalnych, na poziomie struktur społeczno-politycznych i ustaleń prawnych? Czy jako społeczeństwo jesteśmy gotowi na zaakceptowanie i wdrażanie zmian, które sami wywołamy?

\section{BIBLIOGRAFIA}

Baczała, Ditta (2012). Niepełnosprawność intelektualna, a kompetencje społeczne. Toruń: Wydawnictwo Uniwersytetu Mikołaja Kopernika w Toruniu.

Balcazar, Fabricio, Keys, Christopher, Kaplan, Daniel, Suarez-Balcazar, Yolanda (1998). Participatory Action Research and People with Disabilities: Principles and challenges. „Canadian Journal of Rehabilitation”, 12(2), s. 105-112.

Barton, Len (2005). Emancipatory Research and Disabled People: Some Observations and Questions. „Educational Review”, 57(3), s. 317-327.

Bielecka-Prus, Joanna (2013). Paradygmat partycypacyjny w naukach społecznych. Wykorzystywanie danych wytworzonych przez badanych $w$ analizie jakościowej. „Rocznik Lubuski”, t. 39, s. 29-51. 
Brown, Steven (2002). What is Disability Culture. „Disability Studies Quarterly”, 22(2), s. $34-50$.

Burszta, Wojciech (1998). Antropologia kultury. Tematy, teorie, interpretacje. Poznań: Wydawnictwo Zysk i S-ka.

Chodkowska, Maria, Szabała, Beata (2012). Osoby z upośledzeniem umysłowym w stereotypowym postrzeganiu społecznym. Lublin: Wydawnictwo Uniwersytetu Marii Curie-Skłodowskiej w Lublinie.

Firkowska-Mankiewicz, Anna (2006). Zmiana paradygmatu w postrzeganiu osoby z niepetnosprawnościa intelektualna - z podopiecznego na pełnosprawnego i niezależnego uczestnika życia społecznego. W: Barbara Ewa Abramowska (red.). Z Warsztatów Terapii Zajęciowej do pracy - rozwiązania systemowe. Warszawa: Polskie Stowarzyszenie na rzecz Osób z Niepełnosprawnością Intelektualną, s. 11-24.

Gajdzica, Zenon (2013). O roli i pozycji badacza w badaniach rzeczywistości szkoły specjalnej i integracyjnej. „Interdyscyplinarne Konteksty Pedagogiki Specjalnej”, 3, s. 9-19.

Gałecki, Piotr, Święcicki, Łukasz (red.) (2015). Kryteria diagnostyczne z DSM-5, Desk reference. Wrocław: Edra Urban \& Partner.

Geertz, Clifford (2003). Zastane światło. Antropologiczne refleksje na tematy filozoficzne. Przeł. Zbigniew Pucek. Kraków: Universitas.

Główny Urząd Statystyczny (2012). Raport z wyników. Narodowy Spis Powszechny Ludności i Mieszkań 2011. Warszawa: Główny Urząd Statystyczny.

Gustavsson, Andres, Zakrzewska-Manterys, Elżbieta (red.) (1997). Upośledzenie w społecznym zwierciadle. Warszawa: Wydawnictwo ŻAK.

Johnson, Kelley, Minogue, Gerard, Hopkins, Rob (2014). Inclusive Research: Making a Difference to Policy and Legislation. "Journal of Applied Research in Intellectual Disabilities", 27(1), s. 76-84.

McVilly, Keith, Dalton, Arthur (2006). Commentary on Iacono (2006): Ethical Challenges and Complexities of Including People with Intellectual Disability as Participants in Research. „Journal of Intellectual and Developmental Disability”, 31(3), s. 186-188.

Mercer, Geof (2004). From Critique to Practice: Emancipatory Disability Research. W: Colin Barnes, Geof Mercer (red.). Implementing the Social Model of Disability: Theory and Research. Leeds: The Disability Press, s. 118-137.

Niedbalski, Jakub (2016). Dylematy etyczne i problemy metodologiczne warsztatu badacza na przykładzie badań prowadzonych $w$ środowisku osób z niepetnosprawnościa intelektualna oraz niepełnosprawnościa fizyczna. „Studia Humanistyczne AGH”, t. 15/4, s. 35-51.

Oliver, Mike (1997). Emancipatory research: realistic goal or impossible dream? W: Colin Barnes, Geof Mercer (red.). Doing disability research. Leeds: The Disability Press, s. 1531.

Parchomiuk, Monika (2014). „Nic o nas bez nas”. Udział osób z niepetnosprawnościa intelektualną w badaniach. „Człowiek - Niepełnosprawność - Społeczeństwo”, 3(25), s. 35-54. 
Parchomiuk, Monika (2016). Między partycypacja a emancypacją: włączanie osób niepetnosprawnych w badania. „Społeczeństwo i Rodzina”, 1(46), s. 7-25.

Rusinek, Katarzyna (2016). Współczesne ujęcie niepełnosprawności intelektualnej. W: Agnieszka Pawlak-Kindler (red.). Podmiotowość osób z niepetnosprawnościa intelektualna. Lublin: Wydawnictwo Uniwersytetu Marii Curie-Skłodowskiej, s. 11-37.

Taylor, Edward (1871). Primitive Culture: Researchesintothe Development of Mythology, Philosophy, Religion, Art, and Custom. London: John Murray.

Wołowicz, Agnieszka (2018). Badania partycypacyjne jako odpowiedź na założenia społecznego modelu niepełnosprawności? „Studia de Cultura”, 10(1), s. 165-177.

World Health Organization (2007). Atlas: Global Resources for Persons with Intellectual Disabilities. Switzerland: World Health Organization.

Zakrzewska-Manterys, Elżbieta (2010). Upośledzeni umysłowo. Poza granicami człowieczeństwa. Warszawa: Wydawnictwo Uniwersytetu Warszawskiego.

Zarb, Gerry (1997). Researching disabling barriers. W: Colin Barnes, Geof Mercer (red.). Doing Disability Research. Leeds: The Disability Press, s. 49-66.

Zasępa, Ewa (2016). Osoba z niepełnosprawnością intelektualną, procesy poznawcze. Kraków: Oficyna Wydawnicza „Impuls”.

\section{AKTY PRAWNE}

Konwencja o Prawach Osób Niepełnosprawnych z dnia 13 grudnia 2006 r. (Dz.U. 2012, poz. 1169). 